\title{
EFFECTS OF ARBUSCULAR MYCORRHIZAL FUNGI ON MAIZE (ZEA MAYS L.) UNDER ZINC DEFICIENT AND TOXIC FIELD CONDITIONS
}

\author{
SABOOR, A. ${ }^{*}$ - ALI, M. A. ${ }^{*}$ \\ Department of Soil Science, Faculty of Agricultural Sciences and Technology, Bahauddin \\ Zakariya University, Multan, Pakistan \\ (phone: +92-334-682-8007) \\ *Corresponding authors \\ e-mail:abdulsabooruaf36d@gmail.com; arif1056@bzu.edu.pk \\ (Received $7^{\text {th }}$ Oct 2020; accepted $21^{\text {st }}$ Dec 2020)
}

\begin{abstract}
Arbuscular mycorrhizal fungi (AMF) have potential to cope with nutrient stress environment when the soil is zinc $(\mathrm{Zn})$ deficient or toxic. Current study was conducted under field conditions to investigate the potential of mycorrhizal inoculation on maize to mitigate $\mathrm{Zn}$ nutrient stress condition. The treatments were organized according to randomized complete block design under factorial arrangements with three replicates. During this study soil nutrient status and maize nutrient uptake were observed. Soil analysis and determination of different parameters such as chlorophyll contents, total soluble protein including yield parameters was conducted to compare the change in nutrient status with mycorrhizal inoculation. Results showed that mycorrhizal inoculation $(\mathrm{M}+)$ reversed the stress effect of $\mathrm{Zn}$ stress and promoted maize growth. Inoculation increased $\mathrm{Zn}$ uptake by $98 \%$ in $\mathrm{Zn}$ deficient conditions while reduced the uptake of $\mathrm{Zn}$ by $39 \%$ in $\mathrm{Zn}$ toxic conditions. Plants height increased by up to $16 \%$ with fungal inoculation as compared to non-inoculated maize plants. The increased cob length ultimately resulted in higher grain yield with an increase of $15 \%$ and $8 \%$ under medium $\mathrm{Zn}$ toxicity and severe toxicity respectively with mycorrhizal inoculation. Moreover, inoculated maize also showed significant improvement in maize plant root colonization, chlorophyll contents and total soluble protein.
\end{abstract}

Keywords: alkaline soil, growth attributes, physiological growth, yield traits, nutrients

\section{Introduction}

Maize (Zea mays L.) is one of the most abundantly cultivated cereal and fodder crop globally. It is an important cereal crop as it provides essential foodstuff to many people all around the world (Khan et al., 2012). The composition of maize grains comprises of starch, protein, fiber, oil, sugar and ash as described in the literature (Chaudhary, 1993). Limited availability of zinc $(\mathrm{Zn})$ in alkaline calcareous soil is one of the major constraints that hamper maize crop productivity (Joy et al., 2017). Deficiency of $\mathrm{Zn}$ reduces the plant growth due to less auxin production (Brown et al., 1993). According to an estimation of WHO, about $31 \%$ of the world's population have deficiency of Zn (World Health Organization, 2005). As $\mathrm{Zn}$ is an essential micronutrient for animals and plants, it plays important roles in various enzymatic activities involved in protein synthesis, lipid metabolism, carbohydrate and nucleic acid synthesis (Hussain et al., 2011; Ali et al., 2013; Broadley et al., 2007).

Due to its structural, catalytic and co-catalytic function, $\mathrm{Zn}$ plays a significant role in development, reproduction and signaling (Broadley et al., 2007; Cavagnaro, 2008; Roohani et al., 2013) of plants. Zinc takes part in about 300 enzymatic functions, and it is important for plant functioning and growth (Christie et al., 2004; Hacisalihoglu and Kochian, 2000). The studies showed that alkaline calcareous soils of arid and semi-arid regions comprising of $30 \%$ of the soils in the world have deficiency of $\mathrm{Zn}$ (Kochian, 
2000) because of low mobility of Zn (Cakmak et al., 1999; Broadley et al., 2007; Alloway, 2009). In soils with limited $\mathrm{Zn}$ mobility, it becomes very important to understand the mechanisms of $\mathrm{Zn}$ acquisition by plants from the soil (Impa and JohnsonBeebout, 2012). Soil $\mathrm{Zn}$ with less than $1 \mathrm{mg} / \mathrm{kg}$ concentration in soil is considered as deficient, $1-60 \mathrm{mg} / \mathrm{kg}$ is considered as optimum, $60-120 \mathrm{mg} / \mathrm{kg}$ is toxic and above 120 $\mathrm{mg} / \mathrm{kg}$, it is highly toxic (Alloway, 2009). Requirement of $\mathrm{Zn}$ for optimum growth of plants varies among different plant species and crop variety. Maize optimum Zn requirement for its proper growth is $4.7 \mathrm{mg} / \mathrm{kg}$, and for maximizing the maize yield, it should be more than $7 \mathrm{mg} / \mathrm{kg}$ (Liu et al., 2017). Contrarily microbial strains confer positive influence by enhancing root colonization which assist in essential nutrient uptake and mitigates any kind of soil nutrient or abiotic stresses (Shahzad et al., 2017). Arbuscular Mycorrhizal Fungi (AMF) develop a symbiotic association with most of the terrestrial plants and increase uptake of mineral nutrients (Wahid et al., 2016). The AMF are reported to increase $\mathrm{Zn}$ uptake in plants (Rue et al., 1975; Chen et al., 2003; Kafkas and Ortas, 2009; Ortas, 2012). Through this mechanism, AMF can help to cope up Zn deficiency in animals and humans (Cavagnaro, 2008).

Meanwhile, concentration of heavy metals in soils, including $\mathrm{Zn}$ is increasing at a faster rate from the past few decades (Zarcinas et al., 2004). At high level of $\mathrm{Zn}$ in soil, stress is induced in plants, which causes stunted root and shoot growth, death of leaf tips, curling of young leaves, leaf chlorosis, reduced photosynthetic rate, etc. (Rout and Das, 2003; Shi et al., 2015). Environmental $\mathrm{Zn}$ pollution is usually caused by anthropogenic activities like mining, electroplating, smelting and improper waste disposal (Bacon and Dinev, 2005; Bi et al., 2006). High or toxic amount of $\mathrm{Zn}$ availability in soil can have negative effect on plant growth, germination of seeds (Wang et al., 2009), development of roots (Lingua et al., 2008), loss of membrane structure (Stoyanova and Doncheva, 2002) ultimately, leading to the death of cells (Chang et al., 2005).

Under such conditions of high $\mathrm{Zn}$ levels, AMF can play a significant role in improving crop growth and development (He and Nara, 2007; Cavagnaro, 2008). Arbuscular mycorrhizal fungi are symbiotic fungi occurring worldwide, they belong to phylum Glomeromycota (Schubler et al., 2001) and form symbiotic association with the majority of terrestrial plants. The prominent function of AMF is its efficiency in absorbing less mobile nutrients, such as P and Zn (Bolan, 1991; Burkert and Robson, 1994; Marschner and Dell, 1994; Jansa et al., 2003). The role of AMF in absorbing P from the soil is well studied; however, their role for uptake of micronutrients is not well established under field relevant conditions. The study aimed to investigate the effects of arbuscular mycorrhizal fungi on the growth, yield, chlorophyll contents and total soluble protein of maize under toxic or deficit zinc concentrations in a field experiment.

\section{Materials and methods}

The research experiment of the proposed study was conducted in Multan, Punjab, Pakistan at latitude $29^{\circ} 55 \mathrm{~N}$ and longitude $71^{\circ} 31 \mathrm{E}$ (site selected due to $\mathrm{Zn}$ deficiency). Experiment was carried out under field condition at optimized selected toxic and deficient levels of $\mathrm{Zn}$ with and without AMF inoculation. The study comprised of the following treatments $\left(\mathrm{Zn}_{0.45}\right.$ zinc deficiency $0.45 \mathrm{mg} \mathrm{kg}^{-1}, \mathrm{Zn}_{60}$ medium toxicity $60 \mathrm{mg} \mathrm{kg}^{-1}$ and $\mathrm{Zn}_{120}$ zinc toxicity $120 \mathrm{mg} \mathrm{kg}^{-1}$ ) with and without mycorrhizal inoculations. Field soil $\mathrm{Zn}$ levels were maintained by $\mathrm{ZnSO}_{4} .7 \mathrm{H}_{2} \mathrm{O}$ salt addition in the surface soil layer. The treatments were arranged according to randomized complete block design (RCBD) under factorial 
arrangements with three repeats. The net plot size was $6 \mathrm{~m}^{2}$ with $65 \mathrm{~cm}$ row to row and 15.5 $\mathrm{cm}$ plant to plant distance. The hybrid maize cultivar (YH-1898) was sown on $15^{\text {th }}$ July. Mix consortia of mycorrhizal inoculum having glomus species (inoculum purchased from Bustan urban Gardening Essential, Toronto, Canada having 158 propagule/gram) were used as seed priming. In AMF controlled pots (M-), Topsin M (Thiophanate Methyl 70\% WP) was applied at $50 \mathrm{mg} / \mathrm{kg}$ soil, for rendering AMF root colonization. Standard agronomic practices of irrigation with tube well water and recommended dose of nitrogen $(\mathrm{N})$ in three split doses, optimum level of half dose of $(\mathrm{P})$ recommended and potassium $(\mathrm{K})$ fertilizer were applied N:P:K@ 92:29:37 kg acre ${ }^{-1}$, respectively. Other agronomic practices like weed and pest control were also applied. At the time of maturity, full plot was harvested, and root and leaf samples were collected randomly from whole plot and the growth, and physiological parameters were recorded.

\section{Mycorrhizal colonization}

Roots were harvested for AMF root colonization assessment by gridline intersect method (Giovannetti and Mosse, 1980), cleared in 10\% KOH solution and tryphan blue stain was used for staining (Phillips and Hayman, 1970).

\section{Physiological parameters}

Chlorophyll a, b was determined by following the procedure of Arnon (1949). The intensity of green color extract of fresh plant leaves in acetone was measured by a spectrophotometer at 645 and $663 \mathrm{~nm}$ wavelength and chlorophyll a, b was calculated by the formula proposed by Arnon (1949).

$$
\begin{aligned}
& \text { Chlorophyll ' } a \text { ' }\left(\mathrm{mg} \mathrm{g}^{-1}\right)=100 \times[(0.0127 \times A 663-A 645 \times 0.00269)] / 0.5 \\
& \text { Chlorophyll ' } b \text { ' }\left(\mathrm{mg} \mathrm{g}^{-1}\right)=100 \times[(0.0229 \times A 645-0.00468 \times A 663)] / 0.5
\end{aligned}
$$

\section{Nutrient concentration}

All of the fresh plant leaves and roots were removed and rinsed with water and oven dried at $72{ }^{\circ} \mathrm{C}$ for $24 \mathrm{~h}$. Plant leaves and roots fresh weight and oven dried weight was recorded by an analytical/precision electrical balance. Plant $\mathrm{Zn}$ was determined by using standard procedure of atomic absorption spectrophotometer by Lindsay and Norvell (1978) method. Phosphorus in plants was analyzed by following the protocol of malachite green method (Ohno and Zibiliski, 1991). Soil Zn was determined by extractable DTPA$\mathrm{Zn}$ as prescribed by Lindsay and Norvell (1978) and available $\mathrm{P}$ was extracted by sodium bicarbonate solution (Olsen and Sommers, 1982) method and further quantified by malachite green method (Ohno and Zibiliski, 1991). Soil $\mathrm{N}$ analysis was performed by Kjeldahl method (Bremner, 1960) and K was determined by extracting K from soil in ammonium acetate solution by flame photometer instrument (Shuman and Duncan, 1990).

\section{Total soluble protein $\left(\mathrm{mg} \mathrm{g}^{-1}\right)$}

Total soluble protein was measured by using the procedure of Bradford (1976). The plant material $(200 \mu \mathrm{L})$ was extracted from leaves. After this extracted material was added 
into $780 \mu \mathrm{L}$ deionized water and $20 \mu \mathrm{L}$ of coomassie blue dye, and absorbance of this prepared mixture was read at $595 \mathrm{~nm}$ in a spectrophotometer.

\section{Statistical analysis}

The data collected was analyzed statistically using analysis of variance (ANOVA) with arrangement of two factorial randomized complete block design (Steel et al., 1997). Mean values were compared for significance by conducting least significance difference test $(\mathrm{P} \leq 0.05)$. Principal component analysis (PCA) and correlation matrix was performed by using XLSTAT-2014.

\section{Results}

Data regarding mycorrhizal colonization was measured from the roots of both inoculated and un-inoculated maize plants. Significant $(P \leq 0.05)$ proportion increase in mycorrhizal colonization was observed under all zinc deficient and toxic soil conditions (Fig. 1).

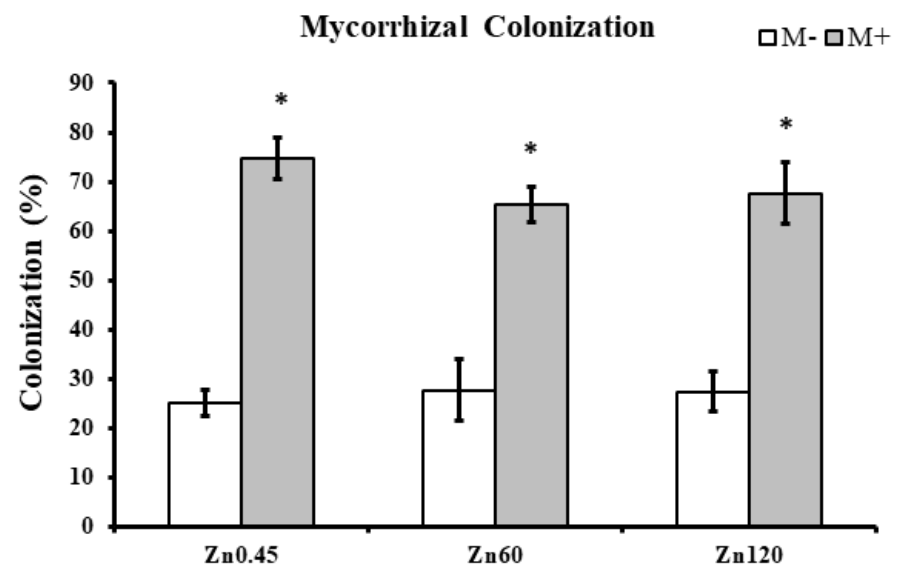

Figure 1. Effect of arbuscular mycorrhizal fungi inoculation on mycorrhizal colonization by maize under zinc deficient and toxic soil conditions $Z n_{0.45}$ zinc deficiency $\left(0.45 \mathrm{mg} \mathrm{Kg}^{-1}\right), Z_{60}$ medium zinc toxicity $\left(60 \mathrm{mg} \mathrm{Kg}^{-1}\right), \mathrm{Zn}_{120}$ severe zinc toxicity $\left(120 \mathrm{mg} \mathrm{Kg}^{-1}\right)$. Inoculated with AMF $(M+$ grey), un-inoculated $(M$ - white). Vertical bars represent standard error and asterisk $(*)$ shows significant difference $(P \leq 0.05)$ among treatments

Soil nutrient status of the $\mathrm{Zn}$ deficient and toxic soil under investigation in the current study was noted. It was observed that the mycorrhizal inoculation enhanced the nutrient status of the soil irrespective of macro nutrients (N and $\mathrm{P}$ ) as well as micronutrient ( $\mathrm{Zn}$ ) (Fig. 2). However, the behavior for $\mathrm{Zn}$ contents was different with the subjected $\mathrm{Zn}$ environment. Soil $\mathrm{Zn}$ content was reported to be increased with the inoculated maize plants under $\mathrm{Zn}$ deficiency $\left(0.45 \mathrm{mg} \mathrm{Kg}^{-1}\right)$, however contrasting results were observed under both medium and severe toxic $\mathrm{Zn}$ growing medium. Maize inoculated plants showed ameliorative effect against $\mathrm{Zn}$ toxicity. Highly significant $(\mathrm{P} \leq 0.05)$ twofold decrease $\left(11.80 \mathrm{mg} \mathrm{Kg}^{-1}\right)$ was noted with inoculation in soil $\mathrm{Zn}$ contents under severe $\mathrm{Zn}$ toxicity (Fig. 2c). 

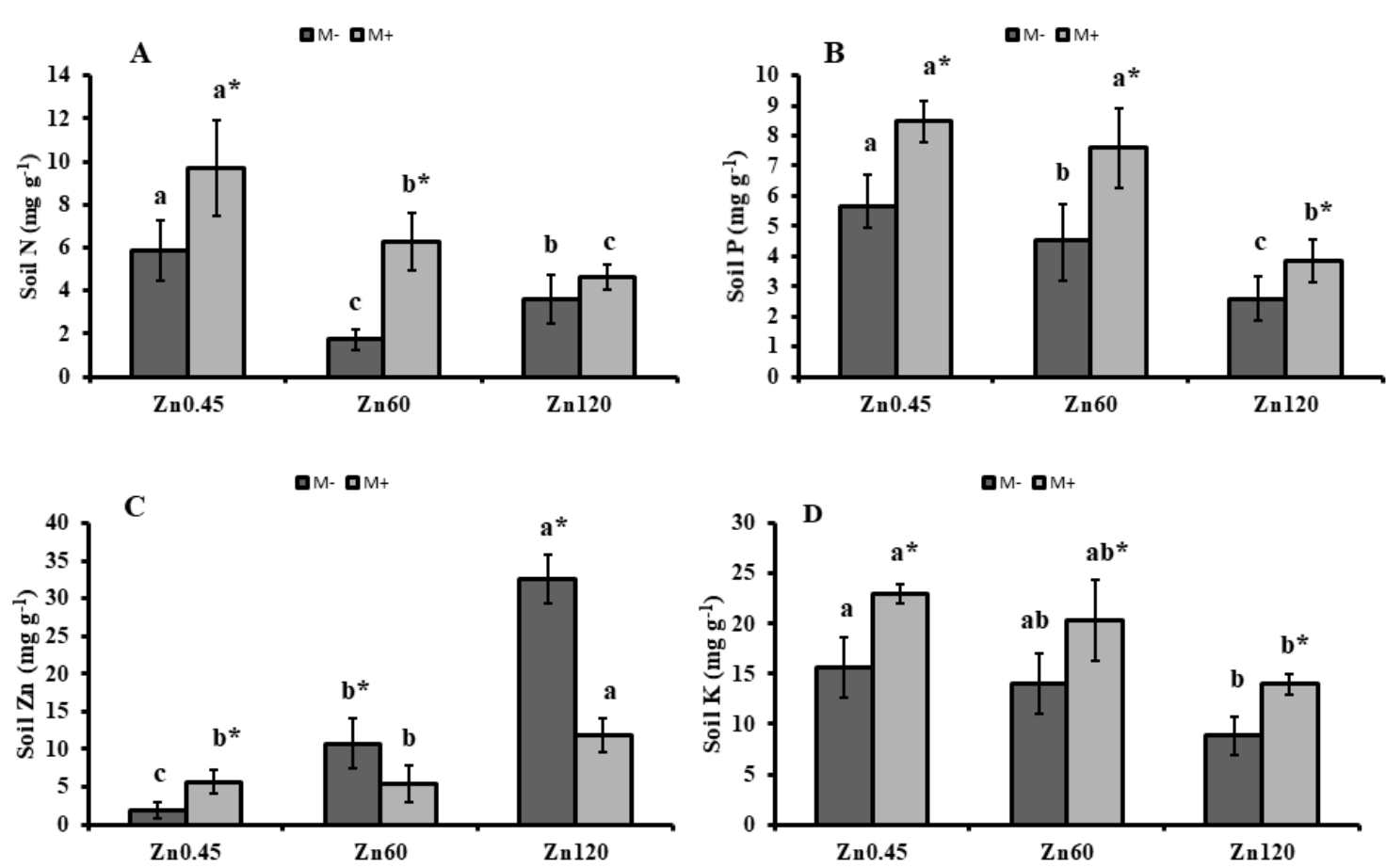

Figure 2. Influence of arbuscular mycorrhizal inoculation maize plants on soil nutrient status under zinc deficient and toxic soil environments. (a) soil nitrogen contents $(b)$ soil phosphorus contents $(c)$ soil zinc contents $(d)$ soil potassium contents. $Z n_{0.45}$ zinc deficiency $\left(0.45 \mathrm{mg} \mathrm{Kg}^{-1}\right), \mathrm{Zn}_{60}$ medium zinc toxicity $\left(60 \mathrm{mg} \mathrm{Kg}^{-1}\right.$ ), $\mathrm{Zn}_{120}$ severe zinc toxicity $\left(120 \mathrm{mg} \mathrm{Kg}^{-1}\right)$. among treatments. Inoculated with AMF $(M+$ grey), un-inoculated $(M-$ white). Vertical bars represent standard error and asterisk $(*)$ shows significant difference $(P \leq 0.05)$ among treatments. Alphabets sharing same letter shows non-significant $(P \geq 0.05)$ difference whereas, different letter shows significant $(P \leq 0.05)$ difference among different treatments

Plant root is the only organ that is in direct contact with the soil environmental adversities and it is also the base of plant for nutrient uptake to ensure sturdy plant growth. Maize nutrient uptake and its accumulation in roots showed contrary results with inoculated and un-inoculated maize plants. Zinc contents in the root of inoculated maize plant were significantly $(\mathrm{P} \leq 0.05)$ higher while in the upper portion (shoots) it was lower. However un-inoculated maize roots showed lower $\mathrm{Zn}$ contents with a decrease of $96 \%$ $\left(0.04 \mathrm{mg} \mathrm{g}^{-1}\right)$ and $\mathrm{P}$ content decrease was of $90 \%\left(1.90 \mathrm{mg} \mathrm{g}^{-1}\right)$ under severe $\mathrm{Zn}$ toxicity (120 mg Kg $\mathrm{g}^{-1}$ ), whereas it created significant nutrient toxic conditions with higher uptake of $\mathrm{Zn}$ in shoots of maize plants (Table 1).

Table 1. Effect of arbuscular mycorrhizal fungi inoculation on nutrient accumulation in roots and its uptake by maize under zinc deficient and toxic soil conditions

\begin{tabular}{c|c|c|c|c|c|c|c|c}
\hline \multirow{2}{*}{} & \multicolumn{2}{|c|}{$\mathbf{Z n}$ in root $\left(\mathbf{m g ~ g}^{-\mathbf{1}}\right)$} & \multicolumn{2}{c|}{$\mathbf{Z n}$ in shoot $\left(\mathbf{m g ~ g}^{\mathbf{- 1}}\right)$} & \multicolumn{2}{c|}{ P in root $\left.\mathbf{( m g ~ g}^{-\mathbf{1}}\right)$} & \multicolumn{2}{c}{ P in Shoot $\left.\mathbf{m g ~ g}^{\mathbf{- 1}}\right)$} \\
\cline { 2 - 8 } & $\mathbf{M}-$ & $\mathbf{M}+$ & $\mathbf{M}-$ & $\mathbf{M}+$ & $\mathbf{M}-$ & $\mathbf{M}+$ & $\mathbf{M}-$ & $\mathbf{M}+$ \\
\hline $\mathrm{Zn}_{0.45}$ & $0.04 \pm 0.00 \mathrm{~b}$ & $0.10 \pm 0.00 \mathrm{a}$ & $5.21 \pm 0.01 \mathrm{a}$ & $3.18 \pm 0.02 \mathrm{c}$ & $1.90 \pm 0.01 \mathrm{e}$ & $3.32 \pm 0.01 \mathrm{~b}$ & $4.14 \pm 0.01 \mathrm{a}$ & $1.51 \pm 0.01 \mathrm{e}$ \\
$\mathrm{Zn}_{60}$ & $0.04 \pm 0.01 \mathrm{~b}$ & $0.09 \pm 0.01 \mathrm{a}$ & $4.59 \pm 0.01 \mathrm{~b}$ & $2.94 \pm 0.03 \mathrm{~d}$ & $2.37 \pm 0.02 \mathrm{c}$ & $5.47 \pm 0.01 \mathrm{a}$ & $3.27 \pm 0.01 \mathrm{~b}$ & $1.77 \pm 0.01 \mathrm{~d}$ \\
$\mathrm{Zn}_{120}$ & $0.02 \pm 0.00 \mathrm{c}$ & $0.04 \pm 0.00 \mathrm{~b}$ & $1.40 \pm 0.03 \mathrm{f}$ & $2.78 \pm 0.03 \mathrm{e}$ & $0.12 \pm 0.01 \mathrm{f}$ & $1.97 \pm 0.02 \mathrm{~d}$ & $0.32 \pm 0.01 \mathrm{f}$ & $2.13 \pm 0.00 \mathrm{c}$ \\
\hline
\end{tabular}

Mean values \pm standard error. Lettering represents significance; different letters shows significant difference $(\mathrm{P} \leq 0.05)$. $\mathrm{Zn}_{0.45}$ zinc deficiency $\left(0.45 \mathrm{mg} \mathrm{Kg}^{-1}\right), \mathrm{Zn}_{60}$ medium zinc toxicity $\left(60 \mathrm{mg} \mathrm{Kg}^{-1}\right), \mathrm{Zn}_{120}$ severe zinc toxicity $\left(120 \mathrm{mg} \mathrm{Kg}^{-1}\right)$ 
Maize plants that were subjected to $\mathrm{Zn}$ deficient $\left(0.45 \mathrm{mg} \mathrm{kg}^{-1}\right)$ and severe toxic (120 $\mathrm{mg} \mathrm{kg}^{-1}$ ) soil conditions exhibited lower chlorophyll $\mathrm{a}$ and $\mathrm{b}$ contents. Maize showed the same trend in decrease of chlorophyll contents in the case of both mycorrhizal inoculation and un-inoculation. Significant $(\mathrm{P} \leq 0.05)$ difference was noted in $\mathrm{chl}$ a and $\mathrm{b}$ contents of maize with AMF inoculated plants under both Zn deficient and toxic soil regimes (Table 1). Maize plants inoculated with AMF showed higher total soluble protein.

Significant differences were noted with all the inoculated plants under varying $\mathrm{Zn}$ levels. The $\mathrm{Zn}_{0.45}$ with mycorrhizal inoculation depicted the highest TSP with an increase of $46 \%$ ( $26.49 \mathrm{mg} \mathrm{g}^{-1}$ ) as compared with the same medium toxicity of $\mathrm{Zn}$ but having nonmycorrhizal inoculation (Table 2).

Table 2. Effect of arbuscular mycorrhizal fungi inoculation on chlorophyll and total soluble protein of maize under zinc deficient and toxic soil conditions

\begin{tabular}{c|c|c|c|c|c|c}
\hline \multirow{2}{*}{} & \multicolumn{2}{|c|}{ Chl a $\left(\mathbf{m g ~ g}^{-1}\right)$} & \multicolumn{2}{c|}{ Chl b $\left.\mathbf{~} \mathbf{m g ~ g}^{-1}\right)$} & \multicolumn{2}{c}{ TSP $\left(\mathbf{m g ~ g}^{-\mathbf{1}}\right)$} \\
\cline { 2 - 7 } & $\mathbf{M -}$ & $\mathbf{M +}$ & $\mathbf{M -}$ & $\mathbf{M +}$ & $\mathbf{M}-$ & $\mathbf{M +}$ \\
\hline $\mathrm{Zn}_{0.45}$ & $1.32 \pm 0.29 \mathrm{c}$ & $1.71 \pm 0.49 \mathrm{a}$ & $0.26 \pm 0.03 \mathrm{e}$ & $0.82 \pm 0.01 \mathrm{a}$ & $18.16 \pm 1.80 \mathrm{~b}$ & $26.49 \pm 1.67 \mathrm{a}$ \\
$\mathrm{Zn}_{60}$ & $1.19 \pm 0.80 \mathrm{~d}$ & $1.62 \pm 0.26 \mathrm{a}$ & $0.38 \pm 0.01 \mathrm{~d}$ & $0.59 \pm 0.02 \mathrm{~b}$ & $13.42 \pm 2.54 \mathrm{c}$ & $18.95 \pm 2.48 \mathrm{~b}$ \\
$\mathrm{Zn}_{120}$ & $1.29 \pm 0.20 \mathrm{~cd}$ & $1.47 \pm 0.36 \mathrm{~b}$ & $0.36 \pm 0.02 \mathrm{~d}$ & $0.51 \pm 0.06 \mathrm{c}$ & $11.36 \pm 1.01 \mathrm{c}$ & $15.93 \pm 0.98 \mathrm{~b}$ \\
\hline
\end{tabular}

Mean values \pm standard error. Lettering represents significance; different letters shows significant difference $(\mathrm{P} \leq 0.05)$. $\mathrm{Zn}_{0.45}$ zinc deficiency $\left(0.45 \mathrm{mg} \mathrm{Kg}^{-1}\right), \mathrm{Zn}_{60}$ medium zinc toxicity $\left(60 \mathrm{mg} \mathrm{Kg}^{-1}\right), \mathrm{Zn}_{120}$ severe zinc toxicity $\left(120 \mathrm{mg} \mathrm{Kg}^{-1}\right)$. Chl a and b (chlorophyll a and b contents of maize), whereas TSP represents total soluble protein

Results showed that mycorrhizal inoculation improved maize growth attributes (plant height, stem girth, no of leaves and plant biomass) under zinc deficient and zinc toxic conditions as compared to maize plants grown in un-inoculated treatments. Significant $(\mathrm{P} \leq 0.05)$ increase of $16 \%$ was observed in plant height with fungal inoculation. The stem girth improved with an increase of $8 \%(8.45 \mathrm{~cm})$ under zinc toxicity. The plants no of leaves were also decreased with zinc toxicity, on the other hand mycorrhizal inoculation resulted in higher number of leaves (Fig. 3).

Results regarding yield attributes of maize are presented in Figure 4. This data showed that mycorrhizal inoculation was effective in improving the yield attributes (cob length and weight, 1000 grain weight, harvest index, biological yield and grain yield) of maize in zinc toxic and deficient conditions. Increase in cob weight, 1000 grain weight, harvest index, biological yield and grain yield of maize was observed in zinc problematic conditions under inoculation compared to treatment without inoculation. The increase in cob length was $30 \%(17.03 \mathrm{~cm})$ under slight zinc toxic soil conditions. The increased cob length resultantly conferred higher grain yield with an increase of $17 \%$ under $\mathrm{Zn}_{0.45}$ zinc toxicity without inoculation to $6.06 \mathrm{Kg} \mathrm{ha}^{-1}$ and $8 \%$ under severe toxicity $3.93 \mathrm{Kg} \mathrm{ha}^{-1}$ to 4.26 Kg ha ${ }^{-1}$ with mycorrhizal inoculation.

\section{Principal component analysis}

The interrelationship among the variables under $\mathrm{Zn}$ deficient and toxic soil were evaluated by biplot principal component analysis (PCA) as shown in Figure 5. It showed that the first two components explained $90.42 \%$ variance (contributed by PC1 $75.78 \%$, and PC2 14.64\%) under Zn deficient and toxic soil SS conditions. PCA biplot showed the grouping of the mycorrhizal and non-mycorrhizal treatments on their response to the 
tested morphological and physiological traits. The mycorrhizal inoculation was highly responsive to influence the tested variables. The $\mathrm{Zn} 1 \mathrm{M}$ (mycorrhizal inoculation under $\mathrm{Zn}$ deficiency) and $\mathrm{Zn} 2 \mathrm{M}$ (mycorrhizal inoculation under medium $\mathrm{Zn}$ toxicity), showed higher response for the variables, i.e., cob weight, grain yield, harvest index, plant height, number of leaves, stem girth, cob length, total soluble protein, potassium in soil, $\mathrm{P}$ accumulation in roots, $\mathrm{Zn}$ in root, nitrogen in soil. The $\mathrm{Zn} 3 \mathrm{M}$ (mycorrhizal inoculation under high zinc toxicity) showed average response. The Zn1NM (non-mycorrhizal under zinc deficiency) showed higher accumulation of $\mathrm{P}$ in shoot. The Zn2NM and Zn3NM were non-responsive to influence the traits of maize.
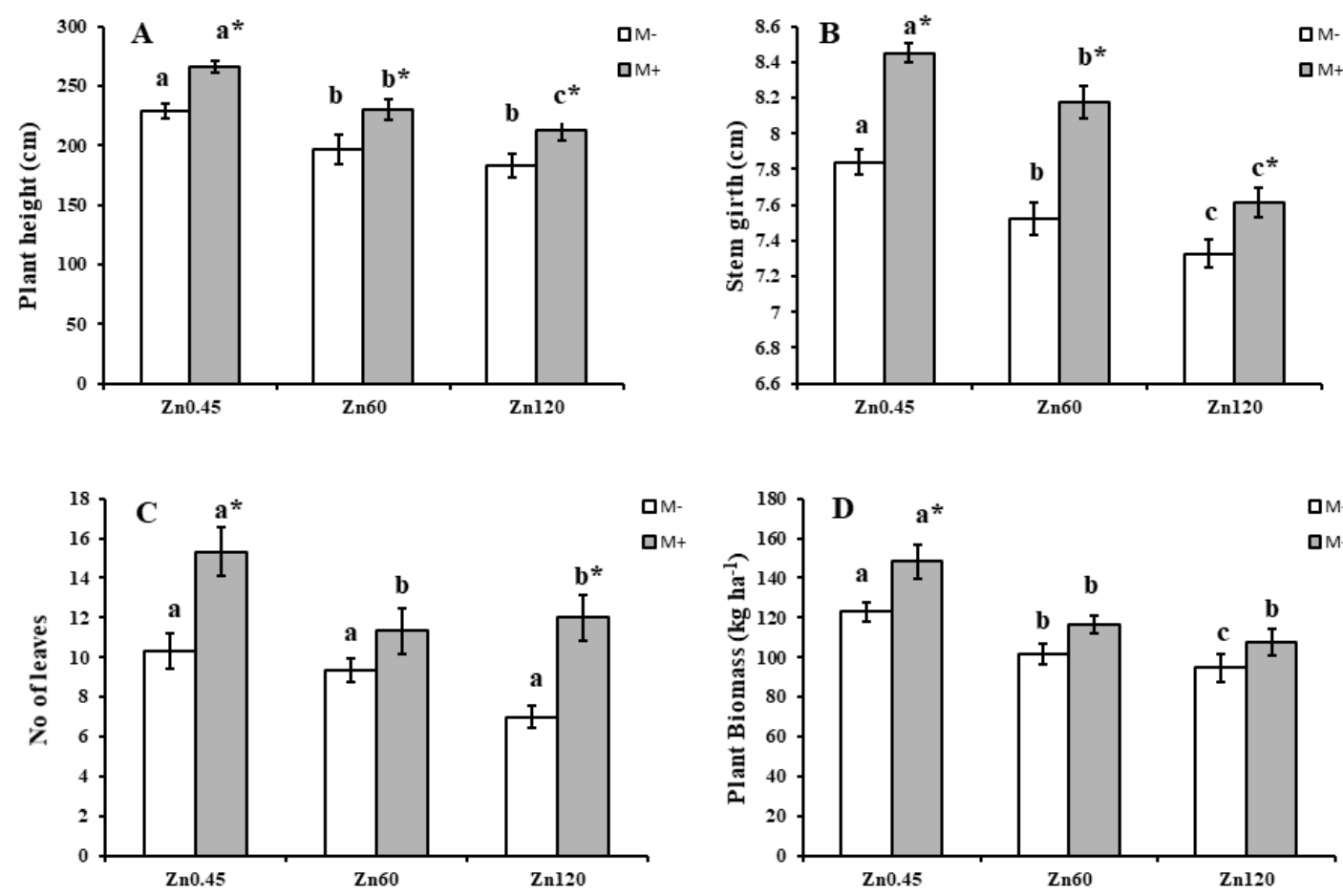

Figure 3. Influence of arbuscular mycorrhizal inoculation on maize growth characteristics under zinc deficient and toxic soil environments. (a) plant height $(\mathrm{cm})(\mathrm{b})$ stem girth (c) no of leaves (d) plant biomass. Zn0.45 zinc deficiency $\left(0.45 \mathrm{mg} \mathrm{Kg}^{-1}\right)$, Zn60 medium zinc toxicity (60 $\left.\mathrm{mg} \mathrm{K \textrm {g } ^ { - 1 }}\right)$, Zn120 severe zinc toxicity $\left(120 \mathrm{mg} \mathrm{Kg}^{-1}\right)$. Inoculated with $\mathrm{AMF}(\mathrm{M}+\mathrm{grey})$, uninoculated $(M-$ white). Vertical bars represent standard error and asterisk $(*)$ shows significant difference $(P \leq 0.05)$ among treatments. Alphabets sharing same letter shows non-significant $(P \geq 0.05)$ difference whereas, different letters show significant $(P \leq 0.05)$ difference among different treatments

\section{Correlation matrix}

Results of Pearson correlation coefficient ( $r$ ) among the morphological and physiological traits of maize under $\mathrm{Zn}$ deficient and toxic soil conditions were summarized in Table 1. Plant height had a strong positive correlation soil N, soil $\mathrm{P}$, soil $\mathrm{K}$ and $\mathrm{Zn}$ in root, and negative correlation with $\mathrm{Zn}$ in soil. Similarly, grain and yield had positive correlation with soil $\mathrm{N}$, soil $\mathrm{P}$ and total soluble protein, whereas both exhibited negative correlation with soil $\mathrm{Zn}$. The soil $\mathrm{P}$ had a positive correlation with soil $\mathrm{N}$ and $\mathrm{K}$, chlorophyll a, and total soluble protein, and a negative correlation with soil $\mathrm{Zn}$, while strongly correlated with $\mathrm{Zn}$ in root (Table 3). 
Table 3. Pearson's correlation between different traits under Zn deficient and toxic soil conditions in maize $(n=6)$

\begin{tabular}{|c|c|c|c|c|c|c|c|c|c|c|c|c|c|c|c|c|c|c|c|c|}
\hline & PH & SG & PB & NL & CL & CW & GW & HI & BY & GY & SN & SP & SZ & SK & ZR & $\mathbf{Z S}$ & PR & PS & CHLA & CHLB \\
\hline PH & & & & & & & & & & & & & & & & & & & & \\
\hline SG & $0.962^{* *}$ & & & & & & & & & & & & & & & & & & & \\
\hline PB & $0.981^{* *}$ & $0.923^{* *}$ & & & & & & & & & & & & & & & & & & \\
\hline NL & $0.926^{* *}$ & $0.861^{*}$ & $0.885^{* *}$ & & & & & & & & & & & & & & & & & \\
\hline CL & $0.947^{* *}$ & $0.922^{* *}$ & $0.904^{* * *}$ & $0.964^{* *}$ & & & & & & & & & & & & & & & & \\
\hline CW & $0.906^{* *}$ & $0.921^{* * *}$ & $0.843^{*}$ & $0.869^{*}$ & $0.836^{*}$ & & & & & & & & & & & & & & & \\
\hline GW & $0.973^{* *}$ & $0.877^{*}$ & $0.963^{* *}$ & $0.957^{* *}$ & $0.933^{* *}$ & $0.859^{*}$ & & & & & & & & & & & & & & \\
\hline HI & $0.948^{* *}$ & $0.840^{*}$ & $0.976^{* *}$ & $0.850^{*}$ & $0.857^{*}$ & $0.762^{*}$ & $0.963^{* *}$ & & & & & & & & & & & & & \\
\hline BY & $0.984^{* *}$ & $0.907^{* *}$ & $0.992^{* *}$ & $0.912^{* *}$ & $0.925^{* *}$ & $0.833^{*}$ & $0.984^{* *}$ & $0.986^{* *}$ & & & & & & & & & & & & \\
\hline GY & $0.925^{* *}$ & $0.885^{* *}$ & $0.963^{* * *}$ & $0.801^{*}$ & $0.791^{*}$ & $0.854^{*}$ & $0.891^{* *}$ & $0.914^{* *}$ & $0.927^{* * *}$ & & & & & & & & & & & \\
\hline SN & $0.932^{* *}$ & $0.901^{* *}$ & $0.929^{* *}$ & $0.823^{*}$ & $0.923^{* *}$ & 0.713 & $0.890^{* *}$ & $0.916^{* *}$ & $0.940^{* *}$ & $0.811^{*}$ & & & & & & & & & & \\
\hline SP & $0.916^{* *}$ & $0.981^{* * *}$ & $0.877^{*}$ & $0.796^{*}$ & $0.842^{*}$ & $0.943^{* *}$ & $0.812^{*}$ & $0.771^{*}$ & $0.842^{*}$ & $0.887^{* *}$ & $0.808^{*}$ & & & & & & & & & \\
\hline SZ & $-0.734^{*}$ & -0.697 & -0.668 & -0.675 & -0.577 & $-0.894^{* *}$ & -0.725 & -0.649 & -0.672 & -0.718 & -0.474 & $-0.749^{*}$ & & & & & & & & \\
\hline SK & $0.937^{* *}$ & $0.981^{* * *}$ & $0.884^{* *}$ & $0.879^{*}$ & $0.900^{* *}$ & $0.971^{* * *}$ & $0.862^{*}$ & $0.784^{*}$ & $0.866^{*}$ & $0.872^{*}$ & $0.812^{*}$ & $0.985^{* *}$ & $-.0770^{*}$ & & & & & & & \\
\hline ZR & $0.866^{*}$ & $0.960^{* *}$ & $0.805^{*}$ & $0.818^{*}$ & $0.885^{* *}$ & $0.888^{* *}$ & $0.760^{*}$ & 0.673 & $0.779^{*}$ & $0.775^{*}$ & $0.796^{*}$ & $0.957^{* * *}$ & -0.601 & $0.967^{* *}$ & & & & & & \\
\hline $\mathbf{Z S}$ & 0.254 & 0.17 & 0.274 & 0.16 & -0.012 & 0.45 & 0.287 & 0.3 & 0.247 & 0.447 & -0.043 & 0.284 & $-0.751^{*}$ & 0.262 & 0.038 & & & & & \\
\hline PR & 0.61 & $0.763^{*}$ & 0.482 & 0.57 & 0.607 & $0.825^{*}$ & 0.477 & 0.338 & 0.461 & 0.495 & 0.456 & $0.824^{*}$ & -0.686 & $0.829^{*}$ & $0.852^{*}$ & 0.19 & & & & \\
\hline PS & 0.128 & 0.026 & 0.125 & 0.065 & -0.118 & 0.335 & 0.186 & 0.185 & 0.123 & 0.269 & -0.158 & 0.127 & -0.704 & 0.121 & -0.113 & $0.970^{* *}$ & 0.114 & & & \\
\hline CHLA & $0.828^{*}$ & $0.871^{*}$ & $0.752^{*}$ & $0.831^{*}$ & $0.938^{* *}$ & 0.716 & $0.766^{*}$ & 0.685 & $0.777^{*}$ & 0.6 & $0.882^{*}$ & $0.782^{*}$ & -0.403 & $0.827^{*}$ & $0.886^{* *}$ & -0.273 & 0.667 & -0.354 & & \\
\hline CHLB & $0.735^{*}$ & $0.780^{*}$ & 0.695 & $0.834^{*}$ & $0.889^{* *}$ & 0.658 & 0.702 & 0.584 & 0.696 & 0.596 & $0.742^{*}$ & 0.71 & -0.271 & $0.777^{*}$ & $0.861^{*}$ & -0.306 & 0.572 & -0.437 & $0.896^{* *}$ & \\
\hline TSP & $0.993^{* *}$ & $0.960^{* *}$ & $0.987^{* *}$ & $0.929^{* * *}$ & $0.957^{* *}$ & $0.880^{*}$ & $0.965^{* *}$ & $0.943^{* *}$ & $0.984^{* *}$ & $0.932^{* *}$ & $0.940^{* *}$ & $0.910^{* * *}$ & -0.668 & $0.931^{* *}$ & $0.877^{*}$ & 0.191 & 0.58 & 0.049 & $0.839^{*}$ & $0.786^{*}$ \\
\hline
\end{tabular}

** significant at $\mathrm{p} \leq 0.01$; significant at $\mathrm{p} \leq 0.05$; PH: Plant height, SG: Stem girth, PB: Plant biomass, NL: No of leaves, CL: Cob length, CW: cob weight, GW: 1000 grain weight, HI: harvest index, BY: biological yield, GY: grain yield, ZR: Zn in root, ZS: Zn in shoot, PR: Phosphorus in root, PS: phosphorus in shoot, PS: phosphorus in soil, ZS: zinc in soil, SN: nitrogen in soil, SZ: zinc in soil, ZS: zinc in shoot, ZR: zinc in root, PR: phosphorus in root, SK: potassium in soil, TSP, total soluble protein, CHLA: chlorophyll a, CHLB: chlorophyll b 

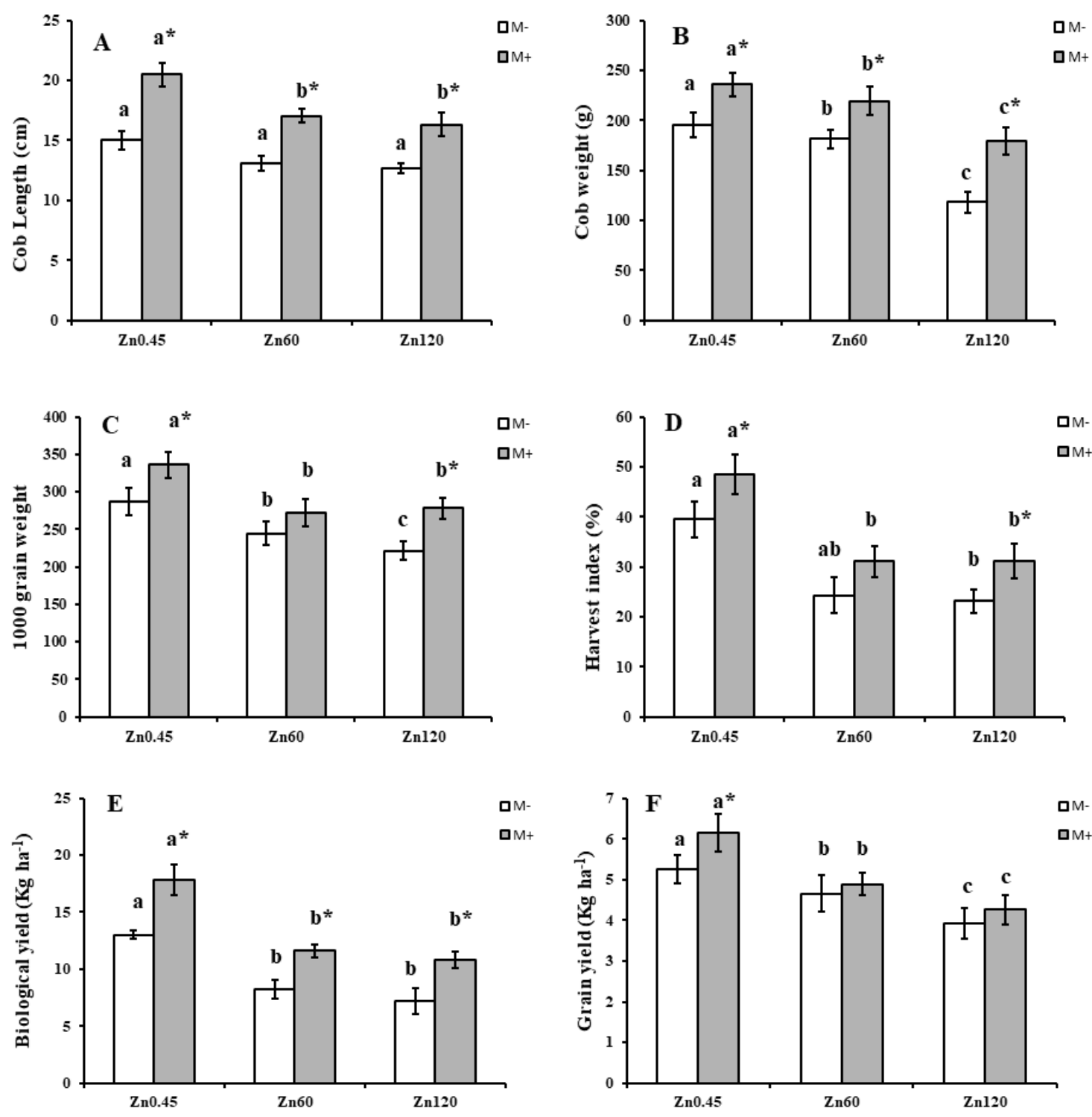

Figure 4. Influence of arbuscular mycorrhizal inoculation maize yield attributes under zinc deficient and toxic soil conditions. (a) cob length (cm) (b) cob weight (c) 1000 grain weight (d) harvest index (e) biological yield (f) grain yield. $Z n_{0.45}$ zinc deficiency $\left(0.45 \mathrm{mg} \mathrm{Kg}^{-1}\right), \mathrm{Zn}_{60}$ medium zinc toxicity $\left(60 \mathrm{mg} \mathrm{Kg}^{-1}\right), \mathrm{Zn}_{120}$ severe zinc toxicity $\left(120 \mathrm{mg} \mathrm{Kg}^{-1}\right)$. Inoculated with AMF $(M+$ grey), un-inoculated $(M-$ white). Vertical bars represent standard error and asterisk (*) shows significant difference $(P \leq 0.05)$ among treatments. Alphabets sharing same letter shows non-significant $(P \geq 0.05)$ difference whereas, different letters show significant $(P \leq 0.05)$ difference among different treatments

\section{Discussion}

Zinc deficiency is a common problem for many cereal crops. The deficiency of $\mathrm{Zn}$ in crops also provide deficient food among their consumers over the extended period. In this way, much of the world's human population cannot fulfil their daily $\mathrm{Zn}$ requirement. This can lead to serious issues regarding human health (Brown and Wuehler, 2000). To avoid nutritional deficiencies, it is important to understand, how plants uptake and utilize $\mathrm{Zn}$ from the soil. While the concern for increasing the 
concentration of $\mathrm{Zn}$ in staple crops is widely recognized (Brown and Wuehler, 2000; Burns et al., 2010). Microbial inoculants have received attention to fortify the micronutrients. If this is to change, we must develop a sound understanding how plants and AMF acquire $\mathrm{Zn}$ from soil. Current study evaluated the effect of mycorrhizal inoculation for plants under deficient and toxic field conditions under optimum $\mathrm{P}$ fertilizer application rates. In this study, mycorrhizal inoculation improved the zinc uptake in zinc deficient condition, while reduced the zinc uptake in zinc toxic concentration. That might be due to myccorhizae prevented zinc deficiency by promoting the plant zinc and phosphorons acquisition and under toxic soil $\mathrm{Zn}$ conditions immoblize $\mathrm{Zn}$, AMF reduced the soil $\mathrm{Zn}$ availability as reported in present study (Chen et al., 2003; Kafkas and Ortas, 2009; Ortas, 2012). Protecting the plants against excessive zinc concentration could also be attributed to mycorrhizal application as mycorrhizae colonize the plant roots lower its uptake and tissue zinc concentration (Chen et al., 2003; Christie et al., 2004). Improvement in phosphorous uptake in stress conditions by mycorrhizal inoculation might be due to that mycorrhizal inoculation solubilized the unavailable phosphorous in stress conditions and promoted the uptake of $P$ in plants (Javot et al., 2007). Improved P nutrition of mycorrhizal maize plants is due to the hyphal $\mathrm{P}$ uptake beyond the $\mathrm{P}$ depletion zone resulting in absorption of $\mathrm{P}$ from the soil solution, which otherwise cannot be replenished, as its mobility is poor in soil (Karandashov and Bucher, 2005). The results of this study are consistent with the earlier report of improved $\mathrm{P}$ uptake in mycorrhizal maize plants (Battini et al., 2017). Our results regarding phosphorus solubilization were further strengthened by the report of Wahid et al. (2016) in maize plants. Results reported in this study showed that mycorrhizal inoculation improved the Chlorophyll ( $\mathrm{a}$ and $\mathrm{b}$ ) contents under zinc stress conditions. This might be due to mycorrhizae increased the uptake of essential nutrients especially $\mathrm{N}$. Increase in $\mathrm{N}$ content in plants promote the chlorophyll content that ultimately assist in improved photosynthetic rate. Results regarding improved chlorophyll contents in response to stress conditions are in agreement with earlier study reported by Sheng et al. (2008). It was also noticed that mycorrhizal inoculation reversed the toxic effect of zinc deficiency and toxicity on maize growth and yield, and improved maize growth such as higher plant height, stem girth, plant biomass, number of leaves and yield attributes which includes cob weight, cob length, 1000 grain weight, harvest index, biological yield and grain yield under zinc toxic and zinc deficient conditions. Improvement in maize growth and yield characteristics under zinc deficient conditions by mycorrhizal inoculation is due to the beneficial role of mycorrhizal inoculation which solubilized unavailable zinc, phosphorous and other essential nutrients and promoted their uptake in maize plants resulting in improved maize growth and yield in zinc deficient conditions (Smith and Read, 2010; Nadeem et al., 2014). The study conducted by Amanullah et al. (2011) also corroborated the results of this study with higher yield of maize with mycorrhizal inoculation in maize plants. While improvement in maize growth and yield attributes under zinc toxic conditions by fungal application might also be due to that inoculation reduced the uptake, accumulation, and translocation of zinc in plant tissues (Smith and Read, 2010). Moreover, it is also due to that mycorrhizal application protects the plants against excessive zinc concentration as mycorrhizae colonize the plant roots, lower uptake and tissue zinc concentration (Chen et al., 2003; Christie et al., 2004). 


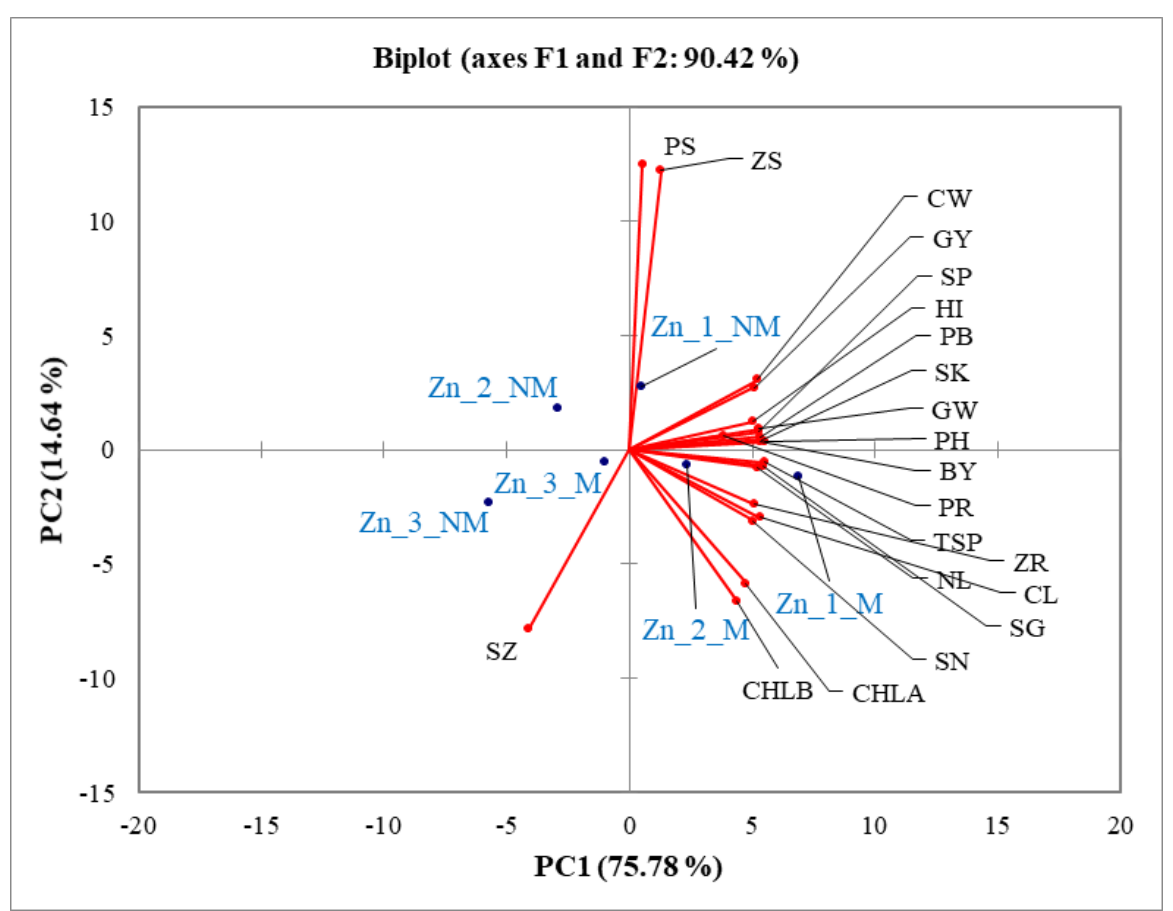

Figure 5. PCA biplot for morpho-physiological variables of maize grown under zinc deficient and zinc toxic soil conditions with mycorrhizal $(M)$ and non-mycorrhizal (NM) inoculations. PCA biplot is a combination of score plot of zinc treatments with $M$ and NM (represented in blue text) and loading plot of variables (represented by red vectors; black text). Zn1: zinc deficiency $\left(0.45 \mathrm{mg} \mathrm{Kg^{-1 }}\right)$, Zn2: Zn60 medium zinc toxicity $\left(60 \mathrm{mg} \mathrm{Kg}^{-1}\right)$, Zn3: Zn120 severe zinc toxicity (120 mg Kg $\mathrm{g}^{-1}$ ), PH: Plant height, SG: Stem girth, PB: Plant biomass, NL: No of leaves,

CL: Cob length, CW: cob weight, GW: 1000 grain weight, HI: harvest index, BY: biological yield, GY: grain yield, ZR: Zn in root, ZS: Zn in shoot, PR: Phosphorus in root, PS: phosphorus in shoot, SP: phosphorus in soil, ZS: zinc in soil, SN: nitrogen in soil, SZ: zinc in soil, ZS: zinc in shoot, ZR: zinc in root, PR: phosphorus in root, SK: potassium in soil, TSP, total soluble protein, CHLA: chlorophyll a, CHLB: chlorophyll b

\section{Conclusion}

It was concluded from the study that mycorrhizal inoculation reversed the stress effect of $\mathrm{Zn}$ deficiency and promoted maize growth, nutrient uptake, and yield. Inoculation of AMF imparted dual beneficial effect on maize as it increased $\mathrm{Zn}$ uptake in $\mathrm{Zn}$ deficient conditions while reduced the uptake of $\mathrm{Zn}$ in toxic conditions. Moreover, it can be suggested by observing the beneficial role of AMF, that it can be used to mitigate $\mathrm{Zn}$ deficiency and toxicity for healthy growth of maize. Further experiments should be conducted for determining the molecular mechanism behind this. Moreover, experiments should be performed on different crops, soils with varying texture, soil $\mathrm{pH}$, nutrient status and moisture contents, as all of these factors strongly influenced $\mathrm{Zn}$ availability and translocation.

\section{REFERENCES}

[1] Ali, M. A., Tariq, N. H., Ahmed, N., Abid, M., Rahim, A. (2013): Response of wheat (Triticum aestivum) to soil applied boron and zinc fertilizers under irrigated conditions. Pakistan of Agriculture Engineering and Veterinary Sciences 29(2): 114-125. 
[2] Alloway, B. J. (2009): Soil factors associated with zinc deficiency in crops and humans. Environmental Geochemistry and Health 31: 537-548.

[3] Amanullah, M. M., Ananthi, T., Subramanian, K. S., Muthukrishnan, P. (2011): Influence of mycorrhiza, nitrogen and phosphorus on growth, yield and economics of hybrid maize. Madras Agricultural Journal 98(1-3): 62-66.

[4] Arnon, D. I. (1949): Copper enzymes in isolated chloroplasts polyphenol oxidase in Beta vulgaris. - Plant Physiology 24: 1-15.

[5] Bacon, J. R., Dinev, N. S. (2005): Isotopic characterization of lead in contaminated soils from the vicinity of a non-ferrous metal smelter near Plovdiv, Bulgaria. - Environmental Pollution134: 247-255.

[6] Battini, F., Grønlund, M., Agnolucci, M., Giovannetti, M., Jakobsen, I. (2017): Facilitation of phosphorus uptake in maize plants by mycorrhizosphere bacteria. - Scientific Reports 7(1): 1-11.

[7] Bi, X., Feng, X., Yang, Y., Qiu, G., Li, G., Li, F., Liu, T., Fu, Z., Jin, Z. (2006): Environmental contamination of heavy metals from zinc smelting areas in Hezhang County, western Guizhou, China. - Environmental International 32: 883-890.

[8] Bolan, N. S. (1991): A critical review on the role of mycorrhizal fungi in the uptake of phosphorus by plants. - Plant and Soil 134: 189-207.

[9] Bradford, M. M. (1976): A rapid and sensitive method for the quantitation of microgram quantities of protein utilizing the principle of protein-dye binding. - Annuals Review of Biochemistry 72: 248-254.

[10] Bremner, J. M. (1960): Determination of nitrogen in soil by the Kjeldahl method. - The Journal of Agricultural Science 55(1): 11-33.

[11] Broadley, M. R., White, J. P., Hammond, J. P., Zelko, L., Lux, A. (2007): Zinc in plants. New Phytologist 173: 677-702.

[12] Brown, K. H., Wuehler, S. E. (2000): Zinc and human health: results of recent trials and implications for program interventions and research. - International Development Research Centre. Ottawa.

[13] Brown, P. H., Cakmak, I., Zhang, Q. (1993): Form and Function of Zinc Plants. - In: Robson, A. D. (ed.) Zinc in Soils and Plants. Springer, Dordrecht, pp. 93-106.

[14] Burkert, B., Robson, A. (1994): Zn uptake in subterranean clover (Trifolium subterraneum) by three vesicular-arbuscular mycorrhizal fungi in a root-free sandy soil. - Soil Biology and Biochemistry 26: 1117-1124.

[15] Burns, A., Gleadow, R., Cliff, J., Zacarias, A., Cavagnaro, T. (2010): Cassava: the drought, war and famine crop in a changing world. - Sustainability 2: 3572-3607.

[16] Cakmak, I., Kalayci, M., Ekiz, H., Braun, H. J., Kilinc, Y., Yilmaz, A. (1999): Zinc deficiency as a practical problem in plant and human nutrition in Turkey: a NATO-science for stability project. - Field Crops Research 60: 175-188.

[17] Cavagnaro, T. R. (2008): The role of arbuscular mycorrhizas in improving plant zinc nutrition under low soil zinc concentration: a review. - Plant and Soil 304: 315-325.

[18] Chang, H. B., Lin, C. W., Huang, J. H. (2005): Zinc-induced cell death in rice (Oryza sativa L.) roots. - Plant Growth Regulation 46: 261-266.

[19] Chaudhary, A. R. (1993): Maize in Pakistan. - Punjab Agri. Res. Cord. Board University of Agriculture, Faisalabad, Pakistan.

[20] Chen, B. D., Li, X. L., Tao, H. Q., Christie, P., Wong, M. H. (2003): The role of arbuscular mycorrhiza in zinc uptake by red clover growing in a calcareous soil spiked with various quantities of zinc. - Chemosphere 50: 839-846.

[21] Christie, P., Li, X., Chen, B. (2004): Arbuscular mycorrhiza can depress translocation of zinc to shoots of host plants in soils moderately polluted with zinc. - Plant and Soil 261: 209-217.

[22] Giovannetti, M., Mosse, B. (1980): An evaluation of techniques for measuring vesicular arbuscular mycorrhizal infection in roots. - New Phytol 84:489-500. https://doi.org/10.1111/j.1469-8137.1980.tb04556.x. 
[23] Hacisalihoglu, G., Kochian, L. V. (2003): How do some plants tolerate low levels of soil zinc? Mechanisms of zinc efficiency in crop plants. - New Phytology 159: 341-350.

[24] He, X., Nara, K. (2007): Element biofortification: can mycorrhizas potentially offer a more effective and sustainable pathway to curb human malnutrition? - Trends in Plant Science 12: 331-333.

[25] Hussain, N., Khan, M. B., Ahmad, R., Ali, M. A., Ahmed, N., Saeed, S. (2011): Physiochemical traits, productivity and net return of wheat as affected by phosphorus and zinc requirements under arid climates. - Pakistan Journal of Botany 43(2): 991-1002.

[26] Impa, S. M., Johnson, S., Beebout, E. (2012): Mitigating zinc deficiency and achieving high grain $\mathrm{Zn}$ in rice through integration of soil chemistry and plant physiology research. - Plant and Soil 361: 3-41.

[27] Jansa, J., Mozafar, A., Frossard, E. (2003): Long-distance transport of P and Zn through the hyphae of an arbuscular mycorrhizal fungus in symbiosis with maize. - Agronomies 23: 481488.

[28] Javot, H., Pumplin, N., Harrison, M. J. (2007): Phosphate in the arbuscular mycorrhizal symbiosis: transport properties and regulatory roles. - Plant, Cell \& Environment 30(3): 310322.

[29] Joy, E. J., Ahmad, W., Zia, M. H., Kumssa, D. B., Young, S. D., Ander, E. L., Watts, M. J., Stein, A. J., Broadley, M. R. (2017): Valuing increased zinc (Zn) fertiliser-use in Pakistan.Plant and Soil 411(1-2): 139-150.

[30] Kafkas, S., Ortas, I. (2009): Various mycorrhizal fungi enhance dry weights, P and Zn uptake of four Pistacia species. - Journal of Plant Nutrition 32: 146-159.

[31] Karandashov, V., Bucher, M. (2005): Symbiotic phosphate transport in arbuscular mycorrhizas. - Trends in Plant Science 10(1): 22-29.

[32] Khan, M. B., Yousaf, F., Hussain, M., Haq, M. W., Lee, D. J., Farooq, M. (2012): Influence of planting methods on root development, crop productivity and water use efficiency in maize hybrids. - Chilean Journal of Agricultural Research 72(4), p.556.

[33] Kochian, L. V. (2000): Molecular physiology of mineral nutrient acquisition, transport, and utilization. - Biochemistry and Molecular Biology of Plants: 1204-1249.

[34] Lindsay, W., Norwell, W. A. (1978): Development of a DTPA soil test for zinc, iron, manganese and copper. - Soil Science Society of America Journal 42:421-428.

[35] Lingua, G., Franchin, C., Todeschini, V., Castiglione, S., Biondi, S., Burlando, B., Parravicini, V., Torrigiani, P., Berta, G. (2008): Arbuscular mycorrhizal fungi differentially affect the response to high zinc concentrations of two registered poplar clones. Environmental Pollution 153: 137-147.

[36] Liu, D. Y., Zhang, W., Yan, P., Chen, X. P., Zhang, F. S., Zou, C. Q. (2017): Soil application of zinc fertilizer could achieve high yield and high grain zinc concentration in maize. - Plant and soil 411(1-2): 47-55.

[37] Marschner, H., Dell, B. (1994): Nutrient-uptake in mycorrhizal symbiosis. - Plant and Soil 159: 89-102.

[38] Nadeem, S. M., Ahmad, M., Zahir, Z. A., Javaid, A., Ashraf, M. (2014): The role of mycorrhizae and plant growth promoting rhizobacteria (PGPR) in improving crop productivity under stressful environments. - Biotechnology Advances 32(2): 429-448.

[39] Ohno, T., Zibilske, L. M. (1991): Determination of low concentrations of phosphorus in soil extracts using malachite green. - Soil Science Society of America Journal 55: 892-895.

[40] Olsen, S. R., Sommers, L. E. (1982): Phosphorus. - In: Page, A. L. et al. (eds.) Methods of Soil Analysis. Part 2 Chemical and Microbiological Properties. American Society of Agronomy, Soil Science Society of America, Madison, pp. 403-430.

[41] Ortas, I. (2012): Do maize and pepper plants depend on mycorrhizae in terms of phosphorus and zinc uptake? - Journal of Plant Nutrition 35: 1639-1656.

[42] Phillips, J., Hayman, D. (1970): Improved procedures for clearing roots and staining parasitic and vesicular-arbuscular mycorrhizal fungi for rapid assessment of infection. - CAB 55(1):158-161. 
[43] Roohani, N., Hurrell, R., Kelishadi, R., Schulin, R. (2013): Zinc and its importance for human shoots of host plants in soils moderately polluted with zinc. - Plant and Soil 261: 209-217.

[44] Rout, G. R., Das, P. (2003): Effect of metal toxicity on plant growth and metabolism: I. Zinc. - Agronomie 23: 3-11.

[45] Rue, J., Clellan, W., Peacock, W. (1975): Mycorrhizal fungi and peach nursery nutrition. California Agriculture 29(5): 6-7.

[46] Schubler, A., Schwarzott, D., Walker, C. (2001): A new fungal phylum, the Glomeromycota: phylogeny and evolution. - Mycological Research 105: 1413-1421.

[47] Shahzad, S., Khan, M. Y., Zahir, Z. A., Asghar, H. N., Chaudhry, U. K. (2017): Comparative effectiveness of different carriers to improve the efficacy of bacterial consortium for enhancing wheat production under salt affected field conditions. - Pakistan Journal of Botany 49(4): 1523-1530.

[48] Sheng, M., Tang, M., Chen, H., Yang, B., Zhang, F., Huang, Y. (2008): Influence of arbuscular mycorrhizae on photosynthesis and water status of maize plants under salt stress. - Mycorrhiza 18(6-7): 287-296.

[49] Shi, W. G., Li, H., Liu X. T., Polle, A., Peng, C. H., Luo, Z. B. (2015): Exogenous abscisic acid alleviates zinc uptake and accumulation in Populus $\times$ canescens exposed to excess zinc. - Plant Cell Environment 38: 207-223.

[50] Shuman, L. M., Duncan, R. R. (1990): Soil exchangeable cations and aluminum measured by ammonium chloride, potassium chloride, and ammonium acetate. - Communications in Soil Science and Plant Analysis 21(13-16): 1217-1228.

[51] Smith, S. E., Read, D. J. (2010): Mycorrhizal Symbiosis. - Academic Press, Cambridge, MA.

[52] Steel, R. G. D., Torrie, J. H., Dickey, D. A. (1997): Principals and Procedures of Statistics. A Biometrical Approach. 3. Ed. - McGraw-Hill Inc Book Co., New York, pp. 352-358.

[53] Stoyanova, Z., Doncheva, S. (2002): The effect of zinc supply and succinate treatment on plant growth and mineral uptake in pea plant. - Brazilian Journal of Plant Physiology 14: 111-116.

[54] Wahid, F., Sharif, M., Steinkellner, S., Khan, M. A., Marwat, K. B., Khan, S. A. (2016): Inoculation of arbuscular mycorrhizal fungi and phosphate solubilizing bacteria in the presence of rock phosphate improves phosphorus uptake and growth of maize. - Pakistan Journal of Botany 48(2): 739-747.

[55] Wang, C., Zhang, S. H., Wang, P. F., Hou J., Zhang, W. J., Li, W., Lin, Z. P. (2009): The effect of excess $\mathrm{Zn}$ on mineral nutrition and antioxidative response in rapeseed seedlings. Chemosphere 75: 1468-1476.

[56] World Health Organization (2005): Comparative Quantification of Health Risks: Global and Regional Burden of Diseases Attributable to Selected Major Risk Factors. Vol. 1-3. - WHO, Geneva.

[57] Zarcinas, B. A., Ishak, C. F., McLaughlin, M. J., Cozens, G. (2004): Heavy metals in soils and crops in Southeast Asia. - Environmental Geochemistry and Health 26: 343-357.

\section{APPENDIX}

Analysis of variance table for biological yield

\begin{tabular}{c|c|c|c|c|c}
\hline Source & DF & SS & MS & F & P \\
\hline Myco & 1 & 69.896 & 69.8956 & & \\
Zinc & 2 & 144.904 & 72.4522 & 65.26 & 0.0000 \\
Error & 14 & 15.544 & 1.1103 & & \\
Total & 17 & 230.344 & & & \\
\hline
\end{tabular}

Grand mean $11.448 \quad$ CV 9.20 
Analysis of variance table for cob length

\begin{tabular}{c|c|c|c|c|c}
\hline Source & DF & SS & MS & F & P \\
\hline Myco & 1 & 85.238 & 85.2383 & & \\
Zinc & 2 & 36.787 & 18.3933 & 9.95 & 0.0020 \\
Error & 14 & 25.877 & 1.8484 & & \\
Total & 17 & 147.902 & & & \\
\hline
\end{tabular}

Grand mean 15.768

CV 8.62

Analysis of variance table for cob weight

\begin{tabular}{c|c|c|c|c|c}
\hline Source & DF & SS & MS & F & P \\
\hline Myco & 1 & 6063.6 & 6063.6 & & \\
Zinc & 2 & 20506.3 & 10253.1 & 69.54 & 0.0000 \\
Error & 14 & 2064.3 & 147.5 & & \\
Total & 17 & 28634.1 & & & \\
\hline
\end{tabular}

Grand mean 193.34 CV 6.28

Analysis of variance table for chlorophyll a

\begin{tabular}{c|c|c|c|c|c}
\hline Source & DF & SS & MS & F & P \\
\hline Myco & 1 & 0.49336 & 0.49336 & & \\
Zinc & 2 & 0.05710 & 0.02855 & 4.48 & 0.0313 \\
Error & 14 & 0.08914 & 0.00637 & & \\
Total & 17 & 0.63960 & & & \\
\hline
\end{tabular}

Grand mean $1.4333 \quad$ CV 5.57

Analysis of variance table for chlorophyll $b$

\begin{tabular}{c|c|c|c|c|c}
\hline Source & DF & SS & MS & F & P \\
\hline Myco & 1 & 0.45442 & 0.45442 & & \\
Zinc & 2 & 0.03484 & 0.01742 & 1.54 & 0.2478 \\
Error & 14 & 0.15798 & 0.01128 & & \\
Total & 17 & 0.64724 & & & \\
\hline
\end{tabular}

Grand mean $0.4944 \quad$ CV 21.48

Analysis of variance table for grain weight

\begin{tabular}{c|c|c|c|c|c}
\hline Source & DF & SS & MS & F & P \\
\hline Myco & 1 & 9038.4 & 9038.40 & & \\
Zinc & 2 & 13254.1 & 6627.07 & 72.21 & 0.0000 \\
Error & 14 & 1284.8 & 91.77 & & \\
Total & 17 & 23577.3 & & & \\
\hline
\end{tabular}

Grand mean 273.25

CV 3.51 
Analysis of variance table for grain yield

\begin{tabular}{c|c|c|c|c|c}
\hline Source & DF & SS & MS & F & P \\
\hline Myco & 1 & 0.92934 & 0.92934 & & \\
Zinc & 2 & 7.40468 & 3.70234 & 153.47 & 0.0000 \\
Error & 14 & 0.33774 & 0.02412 & & \\
Total & 17 & 8.67176 & & & \\
\hline
\end{tabular}

Grand mean 4.8428

CV 3.21

Analysis of variance table for harvest index

\begin{tabular}{c|c|c|c|c|c}
\hline Source & DF & SS & MS & F & P \\
\hline Myco & 1 & 216.94 & 216.944 & & \\
Zinc & 2 & 911.59 & 455.796 & 15.52 & 0.0003 \\
Error & 14 & 411.13 & 29.366 & & \\
Total & 17 & 1539.67 & & & \\
\hline
\end{tabular}

Grand mean $32.402 \quad$ CV 16.72

Analysis of variance table for number of leaves

\begin{tabular}{c|c|c|c|c|c}
\hline Source & DF & SS & MS & F & P \\
\hline Myco & 1 & 72.000 & 72.0000 & & \\
Zinc & 2 & 36.111 & 18.0556 & 6.71 & 0.0090 \\
Error & 14 & 37.667 & 2.6905 & & \\
Total & 17 & 145.778 & & & \\
\hline
\end{tabular}

Grand mean $10.889 \quad$ CV 15.06

Analysis of variance table for plant biomass

\begin{tabular}{c|c|c|c|c|c}
\hline Source & DF & SS & MS & F & P \\
\hline Myco & 1 & 562.24 & 562.242 & & \\
Zinc & 2 & 1883.36 & 941.682 & 65.37 & 0.0000 \\
Error & 14 & 201.68 & 14.406 & & \\
Total & 17 & 2647.28 & & & \\
\hline
\end{tabular}

Grand mean $112.00 \quad$ CV 3.39

Analysis of variance table for plant height

\begin{tabular}{c|c|c|c|c|c}
\hline Source & DF & SS & MS & F & P \\
\hline Myco & 1 & 3618.5 & 3618.45 & & \\
Zinc & 2 & 10581.7 & 5290.87 & 118.57 & 0.0000 \\
Error & 14 & 624.7 & 44.62 & & \\
Total & 17 & 14824.9 & & & \\
\hline
\end{tabular}

Grand mean 222.26 CV 3.01 
Analysis of variance table for phosphorus in roots

\begin{tabular}{c|c|c|c|c|c}
\hline Source & DF & SS & MS & F & P \\
\hline Myco & 1 & 20.2248 & 20.2248 & & \\
Zinc & 2 & 24.8323 & 12.4162 & 76.17 & 0.0000 \\
Error & 14 & 2.2819 & 0.1630 & & \\
Total & 17 & 47.3390 & & & \\
\hline
\end{tabular}

Grand mean 2.5256 CV 15.99

Analysis of variance table for phosphorus in shoot

\begin{tabular}{c|c|c|c|c|c}
\hline Source & DF & SS & MS & F & P \\
\hline Myco & 1 & 2.6912 & 2.69120 & & \\
Zinc & 2 & 8.6987 & 4.34937 & 3.80 & 0.0479 \\
Error & 14 & 16.0036 & 1.14312 & & \\
Total & 17 & 27.3936 & & & \\
\hline
\end{tabular}

Grand mean 2.1889 CV 48.85

Analysis of variance table for mycorrhizal root colonisation

\begin{tabular}{c|c|c|c|c|c}
\hline Source & DF & SS & MS & F & P \\
\hline Myco & 1 & 8149.39 & 8149.39 & & \\
Zinc & 2 & 35.11 & 17.56 & 1.20 & 0.3297 \\
Error & 14 & 204.44 & 14.60 & & \\
Total & 17 & 8388.94 & & & \\
\hline
\end{tabular}

Grand mean $47.944 \quad$ CV 7.97

Analysis of variance table for shoot girth

\begin{tabular}{c|c|c|c|c|c}
\hline Source & DF & SS & MS & F & P \\
\hline Myco & 1 & 1.20125 & 1.20125 & & \\
Zinc & 2 & 1.37301 & 0.68651 & 74.60 & 0.0000 \\
Error & 14 & 0.12883 & 0.00920 & & \\
Total & 17 & 2.70309 & & & \\
\hline
\end{tabular}

Grand mean $7.8206 \quad$ CV 1.23

Analysis of variance table for soil potassium

\begin{tabular}{c|c|c|c|c|c}
\hline Source & DF & SS & MS & F & P \\
\hline Myco & 1 & 177.033 & 177.033 & & \\
Zinc & 2 & 200.406 & 100.203 & 16.71 & 0.0002 \\
Error & 14 & 83.952 & 5.997 & & \\
Total & 17 & 461.391 & & & \\
\hline
\end{tabular}

Grand mean $15.975 \quad$ CV 15.33 
Analysis of variance table for soil nitrogen

\begin{tabular}{c|c|c|c|c|c}
\hline Source & DF & SS & MS & F & P \\
\hline Myco & 1 & 44.305 & 44.3054 & & \\
Zinc & 2 & 55.922 & 27.9612 & 12.51 & 0.0008 \\
Error & 14 & 31.297 & 2.2355 & & \\
Total & 17 & 131.525 & & & \\
\hline
\end{tabular}

Grand mean $5.3033 \quad$ CV 28.19

Analysis of variance table for soil phosphorus

\begin{tabular}{c|c|c|c|c|c}
\hline Source & DF & SS & MS & F & P \\
\hline Myco & 1 & 25.2998 & 25.2998 & & \\
Zinc & 2 & 47.6024 & 23.8012 & 22.95 & 0.0000 \\
Error & 14 & 14.5174 & 1.0370 & & \\
Total & 17 & 87.4196 & & & \\
\hline
\end{tabular}

Grand mean $5.4533 \quad$ CV 18.67

Analysis of variance table for soil zinc

\begin{tabular}{c|c|c|c|c|c}
\hline Source & DF & SS & MS & F & P \\
\hline Myco & 1 & 251.78 & 251.777 & & \\
Zinc & 2 & 1115.27 & 557.636 & 16.60 & 0.0002 \\
Error & 14 & 470.35 & 33.596 & & \\
Total & 17 & 1837.39 & & & \\
\hline
\end{tabular}

Grand mean $11.357 \quad$ CV 51.04

Analysis of variance table for total soluble protein

\begin{tabular}{c|c|c|c|c|c}
\hline Source & DF & SS & MS & F & P \\
\hline Myco & 1 & 209.169 & 209.169 & & \\
Zinc & 2 & 198.507 & 99.253 & 51.94 & 0.0000 \\
Error & 14 & 26.754 & 1.911 & & \\
Total & 17 & 434.430 & & & \\
\hline
\end{tabular}

Grand mean $17.714 \quad$ CV 7.80

Analysis of variance table for zinc in root

\begin{tabular}{c|c|c|c|c|c}
\hline Source & DF & SS & MS & F & P \\
\hline Myco & 1 & 0.00720 & 0.00720 & & \\
Zinc & 2 & 0.00668 & 0.00334 & 18.21 & 0.0001 \\
Error & 14 & 0.00257 & 0.00018 & & \\
Total & 17 & 0.01644 & & & \\
\hline
\end{tabular}

Grand mean $0.0556 \quad$ CV 24.37 
Analysis of variance table for zinc shoot

\begin{tabular}{c|c|c|c|c|c}
\hline Source & DF & SS & MS & F & P \\
\hline Myco & 1 & 2.6758 & 2.67576 & & \\
Zinc & 2 & 14.8597 & 7.42987 & 9.92 & 0.0021 \\
Error & 14 & 10.4899 & 0.74928 & & \\
Total & 17 & 28.0254 & & & \\
\hline
\end{tabular}

Grand mean 3.3511

CV 25.83 